Article

\title{
Toward a More Resilient Financial System: Should Banks Be Diversified?
}

\author{
Laura Baselga-Pascual $^{1, *}$, Olga del Orden-Olasagasti ${ }^{1}$ and Antonio Trujillo-Ponce ${ }^{2}$ (D) \\ 1 Department of Finance and Accounting, University of Deusto, Mundaitz Kalea, 50, \\ 20012 Donostia, Spain; olgadelorden@deusto.es \\ 2 Department of Financial Economics and Accounting, Universidad Pablo de Olavide, \\ Ctra. de Utrera km. 1, 41013 Seville, Spain; atrujillo@upo.es \\ * Correspondence: lbaselga@deusto.es; Tel.: +34-943-326-600
}

Received: 28 February 2018; Accepted: 5 June 2018; Published: 7 June 2018

\begin{abstract}
This article empirically analyzes the effects of revenue diversification on the profitability and risk of a large sample of Eurozone banks over the period from 2000 to 2012. We use the generalized method of moments (GMM) estimator, which is also referred to as the system-GMM estimator. We conclude that higher income diversification favors bank profitability. However, our study does not find a significant relationship between revenue diversification and bank risk, even when considering a crisis period. Our results suggest that establishing restrictions in the universal banking model could damage the resilience of the financial system, and thus affect the sustainability of the uneven economic recovery in Europe.
\end{abstract}

Keywords: diversification; bank profitability; bank risk; dynamic panel; European banking system; sustainability of economic recovery

\section{Introduction}

In the past, bankers believed that they could reduce earnings volatility by diversifying into activities that are imperfectly correlated with traditional banking income [1]. In this vein, studies from Johnson and Meinster [2], Heggestad [3], Wall and Eisenbeis [4], and Litan [5], among others, concluded that banks offering nonbanking products significantly reduced their risk without decreasing their expected returns.

This "conventional wisdom", which is supported by the early literature, initiated a deregulation process in the banking industry in the late 1980s by progressively revoking the Banking Act, known as the Glass-Steagall Act (GSA), from 1933. The deregulation process enabled banks to diversify their asset portfolios and to significantly increase their profits by fostering the emergence of numerous alternative sources of income, such as underwriting, securities trading, brokerage and investment banking, as well as other untraditional banking activities [6,7], leading to the so-called "global financial supermarkets" and "global banks", the most representative company of which was Citigroup. This deregulated scenario, along with an expansionary monetary policy (with low interest rates and easy loans), aimed at alleviating an economic collapse from the burst of the Dotcom bubble at the beginning of the 21st century, is considered one of the main causes of the subprime mortgage and financial crisis (2007-2009) that started in the United States (U.S.) and rapidly spread to Europe [8].

Recommendations for avoiding a repeat of the financial and economic crisis face the challenge of how to meaningfully contribute to a sustainable economic recovery with the help of new banking business models. In response to the global financial crisis, the High-Level Expert Group on reforming the structure of the European Union (EU) banking sector issued a report in 2012 (the so-called Liikanen report), which recommended that proprietary trading and market-making activities be separated from 
other banking activities [9]. The idea of isolating certain types of activities that are considered especially important to the real economy from other riskier, but less important, activities have also been shared by other recent proposals, such as the "Volcker rule" in the United States and the Vickers Commission report in the United Kingdom. These proposals imply restrictions on the universal banking model, in which banks offer a full range of financial services, and thus could lead to less diversified banks [10].

This article complements the existing literature in various ways. First, this work contributes to the ongoing debate surrounding bank diversification by focusing on the Eurozone as an interesting case study. Countries in the Eurozone have become increasingly integrated and set apart from other parts of the EU by their economic management since 1999, following the establishment of the euro. Moreover, the sovereign debt crisis in 2010-2011 highlighted the greater interdependence of countries in the monetary union and emphasized the need to create an integrated financial framework to restore confidence in banks and the euro. The Banking Union, which was initiated in 2012 with the agreement on the establishment of a Single Supervisory Mechanism with the involvement of the European Central Bank (ECB), aims to deliver an integrated financial safety net for these countries. Second, the selected time span, from 2000 to 2012, considers the impact of both the 2008 financial crisis and the sovereign debt crisis starting in 2010 in the European banking sector. As the impact of the financial crisis on the real economy has urged policy makers and regulators to drastically change the "rules of the game" by proposing limits to banking activities, it is important to provide further insights into the effect of revenue diversification on bank performance. Most studies have provided evidence of the effect of revenue diversification under normal economic conditions ([11-13] among others). Third, we use a proxy for revenue diversification that reflects the balance of different types of income (interest, net commissions, trades, and other operating income). Finally, we use the generalized method of moments (GMM) estimator, which was developed for dynamic panel models by Arellano and Bover [14] and Blundell and Bond [15], which is also known as the system-GMM estimator. The system-GMM estimator for dynamic panel data models combines moment conditions for the model in first differences with moment conditions for the model in levels. This method has been shown to improve on the GMM estimator in the first-differenced model in terms of bias and root mean squared error [16]. The system-GMM estimator has also less bias and greater efficiency than either ordinary least squares (OLS) regressions or static panel data models (fixed effects or random effects).

The article is structured as follows: after this introduction, Section 2 reviews the literature; Section 3 describes the data and methodology employed in the empirical research; Section 4 presents and discusses the results; and, Section 5 summarizes and concludes the article.

\section{Literature Review}

Theory provides conflicting predictions about the impact of revenue diversification on the performance of banks. According to Diamond [17] and Stein [18], banks acquire relevant information from their clients in the process of making loans, facilitating the efficient provision of other less traditional services, including underwriting, securities trading, or insurance. Similarly, nontraditional banking activities can produce information that improves lending [19]. Moreover, the sharing of inputs, such as labor, technology, and information across multiple outputs also constitutes a source of potential cost savings for diversified banks [11]. Therefore, part of the literature suggests that revenue diversification provides economies of scope that enhance the profitability of financial institutions. Nevertheless, diversification may reduce bank profits due to agency problems [20] (not only between managers and shareholders, but also between the divisions of the bank and between the bank and its customers in the form of conflicts of interest [11]); regulatory costs that are associated with multiple supervision [11]; or an inefficient resource allocation between different business segments due to a malfunctioning of internal capital markets [21]. Similarly, diversified activities have different theoretical implications for bank risk. Although, according to the portfolio theory, banks may get risk diversification benefits if noninterest income streams are uncorrelated with interest income, diversification can expose banks to new forms of risks (in addition to credit risk), such as market, 
liquidity, and operational risk [22]. Furthermore, diversified banks may operate with lower capital ratios and pursue riskier activities because many fee-based activities can be performed while holding little or no regulatory capital [23].

The empirical literature has also reported the opposing effects of revenue diversification on bank performance. Chiorazzo et al. [24] concluded that noninterest income increases risk-adjusted returns for a sample of Italian banks, with this relationship stronger for larger banks. Köhler [25] concluded that retail-oriented banks, such as savings, cooperative, and other banks that focus on lending and deposit services, become significantly more stable (in the sense of having higher Z-scores) if they increase their share of noninterest income. Köhler [26] analyzed the impacts of business models on bank stability in 15 EU countries between 2002 and 2011, indicating that substantial benefits can be gained from income diversification. Brighi and Venturelli [27] reported evidence suggesting that greater diversification among different fee and commission components decreases bank risk and increases risk-adjusted profitability. Elsas et al. [28] showed that diversification increases bank profitability and market valuation. Lee et al. [29] concluded that bank performance can be improved through diversification, confirming the hypothesis of the portfolio diversification effect for the Asia-Pacific banking industry. Sanya and Wolfe [30] and Meslier et al. [9] focused on banks in emerging economies and provided empirical evidence that an observed shift toward noninterest income-generating activities has a positive effect on bank performance and it decreases the risk of insolvency. Finally, the benefits of revenue diversification have also been confirmed in some African countries [31,32].

Nevertheless, there is also a large body of empirical studies concluding that diversification has detrimental effects on bank performance. Mercieca et al. [12] found an inverse association between noninterest income and performance for small banks. Lepetit et al. [13] showed that expansion into noninterest income activities, particularly into activities with increased commissions and fees and increases insolvency risk. De Jonghe [33] stated that noninterest income-generating activities increased the systemic risk of Eurozone banks over the period of 1992-2007. DeYoung and Rice [34] and Stiroh and Rumble [35] showed that increased noninterest income is associated with poorer risk-return tradeoffs in U.S. banks. Saona [36] stated that noninterest income activities are negatively and significantly correlated with profitability in Latin American banks. Laeven and Levine [19] examined an international sample of financial conglomerates and found that their respective market values reflect a diversification discount; i.e., the market values are lower than if those financial conglomerates were broken up into financial intermediaries that specialize in the individual activities. Finally, Demirgüç-Kunt and Huizinga [37] and Baele et al. [11] reported negative effects of diversification on bank risk, although they found positive effects on asset returns and franchise values, respectively.

Table 1 provides a summary of the main findings on revenue diversification in the empirical literature. 
Table 1. Summary of the findings on the impacts of revenue diversification on bank profitability and bank risk.

\begin{tabular}{|c|c|c|c|}
\hline References & Sample & Period & Empirical Findings \\
\hline [7] & Philippines & 1999-2005 & $\begin{array}{l}\text { A shift toward noninterest activities increases bank profits and risk-adjusted profits, particularly when banks are more involved in trading } \\
\text { in government securities. }\end{array}$ \\
\hline [11] & $15 \mathrm{EU}$ countries + Norway and Switzerland & 1989-2004 & $\begin{array}{l}\text { A higher share of noninterest income among total income affects banks' franchise values positively. Diversification of revenue streams from } \\
\text { distinct financial activities increases the systematic risk of banks, while the effect on the idiosyncratic risk component is nonlinear and } \\
\text { predominantly downward sloping. }\end{array}$ \\
\hline [12] & Europe (small banks) & $1997-2003$ & $\begin{array}{l}\text { A shift from interest income activities to noninterest income activities results in lower performance of small European banks, caused by } \\
\text { weak monitoring of activities that lie outside of their traditional lending business. }\end{array}$ \\
\hline [13] & Europe & 1996-2002 & $\begin{array}{l}\text { Banks expanding into noninterest income activities present greater risk and greater insolvency risk than banks that mainly supply loans. } \\
\text { The positive link with risk is mostly accurate for small banks and is essentially driven by commissions and fee activities. }\end{array}$ \\
\hline [19] & International ( 43 countries) & 1998-2002 & $\begin{array}{l}\text { The market values of financial conglomerates that engage in multiple activities (i.e., lending and non-lending financial services) are lower } \\
\text { than if those financial conglomerates were broken up into financial intermediaries that specialize in individual activities. }\end{array}$ \\
\hline [24] & Italy & 1993-2003 & $\begin{array}{l}\text { Income diversification increases risk-adjusted returns, with this relationship stronger with larger banks. Small banks can profit from } \\
\text { increasing noninterest income but only when they have very little noninterest income share in the beginning. }\end{array}$ \\
\hline [25] & Germany & 2002-2012 & $\begin{array}{l}\text { The impact of noninterest income on bank risk differs between retail- and investment-oriented banks: while retail-oriented banks become } \\
\text { significantly more stable (in the sense of having a higher Z-score), if they increase their share of noninterest income, investment-oriented } \\
\text { banks become significantly riskier. }\end{array}$ \\
\hline [26] & $15 \mathrm{EU}$ countries & 2002-2011 & $\begin{array}{l}\text { Banks are significantly more stable and profitable if they increase their share of noninterest income. Such benefits are particularly large for } \\
\text { savings and cooperative banks. Investment banks, in contrast, become significantly riskier. }\end{array}$ \\
\hline [27] & Italy & 2006-2012 & Greater revenue diversification decreases bank risk and increases risk-adjusted profitability, especially after crisis periods. \\
\hline [28] & U.S., Canada, Australia and Europe & 1996-2008 & $\begin{array}{l}\text { Diversification increases bank profitability and, as a consequence, market valuations. This evidence against a conglomerate discount in } \\
\text { banking also remained robust during the subprime mortgage crisis. }\end{array}$ \\
\hline [29] & Asia-Pacific & 1995-2009 & $\begin{array}{l}\text { Bank performance can be improved through diversification in bank-based groups. Under different financial systems, the relationships } \\
\text { among revenue diversity, financial reforms and bank performances are multidimensional. }\end{array}$ \\
\hline [30] & 226 listed banks across 11 emerging economies & 2000-2007 & Revenue diversification decreases insolvency risk and enhances profitability. \\
\hline [31] & Africa & 1996-2014 & There is a positive relationship between bank market power and income from nontraditional activities. \\
\hline [32] & Africa & $2002-2013$ & Cross-border banking and revenue diversification within banks in Africa can create value. \\
\hline [33] & $15 \mathrm{EU}$ countries & 1992-2007 & Noninterest-generating activities increase banks' tail beta. \\
\hline [34] & U.S. & 1989-2001 & $\begin{array}{l}\text { Small, well-managed banks generate less noninterest income. Marginal increases in noninterest income are associated with higher and } \\
\text { more variable profits and with worsening of the risk-return trade-off for the average commercial bank. }\end{array}$ \\
\hline [35] & U.S. & $1997-2002$ & $\begin{array}{l}\text { Diversification benefits exist between Financial Holding Companies (FHCs), but these gains are offset by increased exposure to noninterest } \\
\text { activities, which are much more volatile but not necessarily more profitable than interest-generating activities. }\end{array}$ \\
\hline [36] & Latin America & 1995-2012 & There is a negative relationship between bank profitability and revenue diversification. \\
\hline [37] & International (101 countries) & 1995-2007 & $\begin{array}{l}\text { Expansion into noninterest income-generating activities, such as trading, increases the rate of return on assets, and it could offer some risk } \\
\text { diversification benefits at very low levels. Overall, banking strategies that rely prominently on generating noninterest income are very risky }\end{array}$ \\
\hline
\end{tabular}




\section{Data and Methodological Aspects}

\subsection{Sample}

We use a sample consisting of an unbalanced panel with 4268 observations that were obtained from commercial banks, savings banks, and credit cooperatives operating in 14 European countries over the period from 2000 to 2012. We restrict the analysis to countries that adopted the euro during the sample period and thus have a common monetary policy: Austria, Belgium, Finland, France, Germany, Greece, Ireland, Italy, Luxembourg, the Netherlands, Portugal, Slovakia, Slovenia, and Spain (see Table 2). Because banks must have information available for all of the variables analyzed for at least five consecutive years to test the second-order serial correlation when the system-GMM methodology is used [38], we exclude some countries (e.g., Estonia). Unlike previous studies that focused only on listed banks (e.g., [8]), our sample includes all (listed and unlisted) banks in the euro area (commercial, savings, and cooperative banks), which affords us a more representative picture of the European banking sector, as unlisted banks account for the majority of banks in this area [26].

Table 2. Observations in the sample by country.

\begin{tabular}{cc}
\hline Country & Observations \\
\hline Austria & 57 \\
Belgium & 29 \\
Finland & 39 \\
France & 700 \\
Germany & 1156 \\
Greece & 50 \\
Ireland & 51 \\
Italy & 1642 \\
Luxembourg & 32 \\
Netherlands & 77 \\
Portugal & 97 \\
Slovakia & 40 \\
Slovenia & 90 \\
Spain & 208 \\
Total Eurozone & 4268 \\
\hline
\end{tabular}

Bank balance sheet data and income statements are obtained from the BankScope database that was maintained by Bureau Van Dijk (now Orbis Bank Focus). Indicators are calculated on a nonconsolidated basis, indicating that banking subsidiaries and foreign branches are considered to be separate credit institutions. This assumption reduces the possibility of introducing aggregation bias into the results [39]. Merged banks are considered as separate entities before the merger and a single entity subsequently. All of the ratios capturing bank-specific characteristics are calculated based on the standardized global accounting format. Entities that present abnormal ratios or extreme values are eliminated from the sample as outliers in order to ensure that the analysis is not affected by potential measurement errors and misreporting. The frequency of the data is annual.

We obtain the data on industry concentration from the Banking Structural Financial Indicators database of the European Central Bank (ECB), whereas macroeconomic data are obtained from Eurostat.

\subsection{Methodology}

Bank-specific factors determining bank profitability and risk can be endogenous. For example, more profitable banks can have more resources to increase their equity; such banks might also find it easier to increase their customer base through successful advertising, and thereby enhance their profitability [40]. Similarly, banks could have incentives to increase their stock of liquid assets if they become riskier to protect themselves against premature withdrawals of funds [26]. In addition to endogeneity, some characteristics that affect bank performance are difficult to measure or to identify 
in an equation (so-called unobserved heterogeneity). If the influence of such characteristics is not considered, then one could observe correlations between some of the coefficients of the explanatory variables and the error terms that bias these coefficients. Finally, the persistence of profitability and risk has been well documented in the literature. To address these concerns, we use the GMM estimator that was developed for dynamic panel models by Arellano and Bover [14] and Blundell and Bond [15], also referred to as the system-GMM estimator. This methodology is a better alternative than traditional panel data estimators, which can produce biased and inconsistent estimates when being applied to our equation. Following Windmeijer [41], we use the two-step estimation procedure with finite sample corrected standard errors, providing less biased coefficient estimates and more accurate standard errors.

Our baseline equation is as follows:

$$
Y_{i, j, t}=\alpha+\delta \cdots Y_{i, j, t-1}+\beta \cdots D I V_{i, j, t}+\lambda \cdots B S_{i, j, t}+\gamma \cdots M_{j, t}+\theta \cdots R_{j, t-1}+\eta \cdots D_{i, j, t}+\varepsilon_{i, j, t}
$$

where $Y$ denotes the variable used to measure either the profitability or the risk of bank $i$ in country $j$ in year $t ; Y_{i, t-1}$ represent their lagged values; $\delta$ measures the speed of adjustment (a value of $\delta$ close to 0 implies that bank profitability/risk is characterized by a high speed of adjustment, whereas a value that is close to 1 indicates that the adjustment is very slow); DIV represents a proxy of revenue diversification; $B S_{i, j, t}$ and $M_{j, t}$ denote, respectively, the bank-specific and the industry and macroeconomic variables that were considered in our study; $R_{j, t-1}$ refers to several bank regulation and supervision control variables; and, $D_{i, j, t}$ represents dummy variables controlling for the public status of the bank and the bank type. $\beta, \lambda, \gamma, \theta$, and $\eta$ are vectors of coefficient estimates. Finally, $\varepsilon_{i, t}$ is the disturbance term that contains the unobserved bank-specific effect $\left(\eta_{i}\right)$ and the idiosyncratic error $\left(v_{i, t}\right)$.

\subsection{Measures of Profitability and Risk}

More than $90 \%$ of the banks in our sample are unlisted, providing us with a broad representation of the Eurozone banking system, but requiring us to use accounting-based, instead of market-based, indicators. However, we acknowledge that accounting metrics have limitations. For instance, managers could use some timing discretion over these metrics to minimize regulatory costs. They are also backward looking [42].

We consider the return on average assets (ROA) as our proxy for bank profitability, which is the single most important ratio for comparing the efficiency and operational performance of banks [40]. ROA is computed as pretax profits that are divided by total assets. This ratio considers the returns that are generated from the assets that a bank finances; it is primarily an indicator of managerial efficiency, although it can be misleading as a result of off-balance-sheet activities. Our measure of bank risk is the Z-score, defined as the number of standard deviations that a bank's return on assets must fall below the mean for the bank to become insolvent [43]. Therefore, this index can be interpreted as an inverse measure of the probability of insolvency; i.e., a higher Z-score indicates that a bank incurs fewer risks and is more stable [26]. The Z-score is considered to be a better measure of bank risk than the nonperforming loan ratio (NPLr) because nonperforming loans are traditionally backward looking and highly procyclical $[44,45]$. In addition, the Z-score is an overall measure of bank risk that captures more than credit risk alone [46]. The Z-score is calculated as the sum of ROA and equity-to-assets ratio (Eq/TA), divided by the three-year standard deviation of ROA ( $\left.\mathrm{SD}_{\mathrm{ROA}}\right)$ :

$$
\text { Z-score } e_{t}=\frac{\mathrm{ROA}_{\mathrm{t}}+\mathrm{Eq} / \mathrm{TA}_{\mathrm{t}}}{\mathrm{SD}_{\mathrm{ROA}}}
$$

Finally, we calculate natural logarithms to control for the skewness that was exhibited by the original metric. 


\subsection{Revenue Diversification}

Following Elsas et al. [28], we proxy revenue diversification using a Herfindahl-Hirschman index (HHIRD) that reflects the balance of different types of income, such as interest, net commissions, trading, and other operating income. HHIRD is calculated, as follows:

$$
\text { HHIRD }=1-\left[\left(\frac{\mathrm{INT}}{\mathrm{TOR}}\right)^{2}+\left(\frac{\mathrm{COM}}{\mathrm{TOR}}\right)^{2}+\left(\frac{\mathrm{TRAD}}{\mathrm{TOR}}\right)^{2}+\left(\frac{\mathrm{OTH}}{\mathrm{TOR}}\right)^{2}\right]
$$

where INT denotes gross interest income; COM denotes gross commissions and fee revenue; TRAD denotes trading revenue; and, OTH denotes all other gross operating income. TOR represents total operating revenue and is equal to the sum of the absolute values of INT, COM, TRAD, and OTH. HHIRD can take values between 0 (no revenue diversification) and 75 (indicating a bank that generates a fully balanced revenue mix from all four business areas).

\subsection{Control Variables}

We include in our regression several bank-specific variables, the influences of which on bank profitability and risk have been widely contrasted in the literature (see [26,40,43,47]). We control for the bank's asset structure using the ratio of loans to total assets (Loan/TA), as the literature suggests that this ratio is positively correlated with bank returns [7] and risk [12,43]. The effect of capitalization on bank performance is controlled for using Eq/TA. We expect a positive effect of capitalization on ROA. There appears to be a consensus in the previous literature that more capital (and therefore, better solvency) reduces the costs of external debt, compensating for the higher costs of one's own funds [40]. Consistent with previous studies (e.g., [23,35]), a negative relationship between bank capitalization and risk can be expected due to the potential danger of leverage. The recent financial crisis has clearly exposed the risks of a bank's excessive reliance on non-deposit funding; thus, following Laeven and Levine [19] and Köhler [26], among others, we include in our equation the ratio of non-deposit funds to total liabilities (NonDep/TL). We control for operational efficiency using the cost-to-income ratio (CIR), which can be negatively related to bank returns [23] but positively related to risk [47]. The natural logarithm of bank assets accounts for the effect of size on bank performance (Size) The effect of size on bank returns could be nonlinear, with profitability initially increasing with size and then declining for bureaucratic and other reasons [48]. However, the effect of size on bank risk-taking remains unclear: although larger banks might incur more risk due to a moral hazard problem [26,33], they might be less prone to risk because of their managerial capacity and efficiency [12]. We also include the NPLr to account for credit risk in the profitability equation [40]; and the ROA to account for profitability in the risk equation [43].

We additionally control for industry concentration, which is measured in terms of the Herfindahl-Hirschman index (HHIIC), which is calculated as the sum of the squares of all credit institutions' market shares within a country in terms of total assets (in percentages). We further include selected macroeconomic variables, following previous studies: (i) the annual growth rate of the real gross domestic product of the country (GDP), which controls for the effect of economic growth in our regressions [40,43]; (ii) the consumer price index annual average rate of change (Inflation), as inflation could affect both bank profitability and bank risk [26,40]; (iii) the annual average unemployment rate (UR), which could negatively affect the returns and the risks of banks [43,47]; and, (iv) the interest rate of the main refinancing operations of the European Central Bank (Interest). An environment of low interest rates can exert pressure on the operating margin and negatively affect banks' profitability [49,50]. It could also affect bank risk [43].

Moreover, as there still might be some differences in the regulatory and supervisory environments between each country's banking system inside the Eurozone [43], we use four indices from the World Bank database on "Bank Regulation and Supervision", as developed by Barth et al. [51] as regulation controls in our equation specification (see Appendix A). This database is based on four 
surveys conducted by the World Bank (Survey I was released in 2001, and for most of the countries, the information corresponds to 1999; Survey II describes the regulatory situation at the end of 2002; Survey III describes the regulatory environment in 2005-2006; Survey IV provides information about bank regulation and supervision in 125 countries for 2011 (with some corrections in 2012) [52]). The capital stringency index evaluates the regulatory approach to assessing and verifying the degree of capital at risk in a bank; the supervisory power metric reflects the degree to which the country's bank supervisory agency has the authority to undertake specific actions (e.g., force a bank to change its internal organizational structure); the private monitory index shows the degree to which banks are forced to disclose accurate information to the public and whether there are incentives to increase market discipline; and finally, the activity restrictions index measures the degree to which banks face regulatory restrictions on their activities in securities markets, insurance, and real estate, as well as on owning shares in nonfinancial firms, with higher values indicating greater restrictions [36]. We use the first lag of these indices, as regulative initiatives are unlikely to affect bank profitability and/or bank risk immediately $[39,46]$.

Finally, we control for the public status of the bank-as market discipline exerted by the stock market might influence bank performance [53]—and for the bank type—as commercial banks, savings banks, and credit cooperatives have different business models, objectives, and ownership structures [26].

Table 3 summarizes the variables considered in the current study.

Table 3. Variables considered in the study.

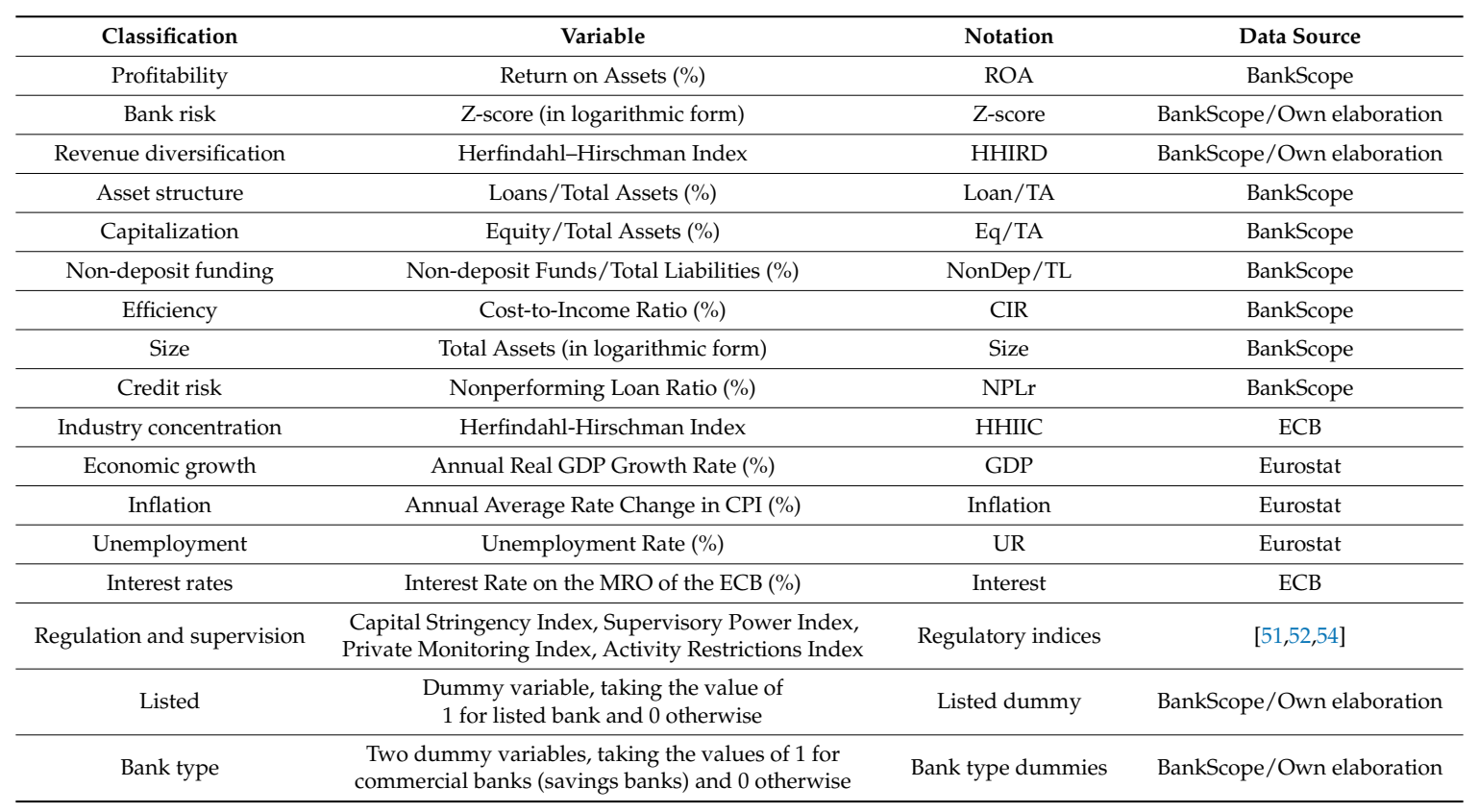

\subsection{Endogeneity}

We acknowledge that there is a problem of endogeneity in our regression. To address it, the system-GMM estimator uses suitable instruments. In line with Arellano and Bover [14] and Blundell and Bond [15], we employ lagged first differences of the bank-specific variables as instruments for the equation in levels and the lagged values of these variables in levels as instruments for the equation in differences. Regulatory and supervisory indicators are also treated as endogenous, as we assume that the regulators may change banking rules to prevent financial turbulence if they observe low profitability and/or excess risk taking $[39,43]$. The public status of the bank is considered to be endogenous in our equation, as banks may choose to become listed or not, based on the expected future changes in profitability and/or risk [43]. The industry concentration, macroeconomic variables, 
and bank type dummies are treated as exogenous. We verify that the instruments are statistically valid using Hansen's J-test of over identifying restrictions.

\section{Empirical Results}

\subsection{Results from the Baseline Model}

Table 4 presents descriptive statistics of the variables that are considered in this paper. The average ROA for banks in the sample is $0.48 \%$ with a standard deviation of $0.82 \%$. As reported by Baselga-Pascual et al. [43], profitability levels have remained low since the onset of the crisis in 2008 and they have been characterized by a high degree of heterogeneity. Banks have, on average, a Z-score (calculated in logarithmic form) of 3.58, with a standard deviation of 1.01. The index of revenue diversification has a mean value of 35.89, indicating that Eurozone banks present a certain degree of diversification in the origin of their income (interest, commissions and fees, trading, and other operating income). Most of the control variables have the expected values, demonstrating in the macroeconomic variables the deterioration of the economic situation in the Eurozone.

Table 4. Descriptive statistics.

\begin{tabular}{ccccccc}
\hline Variable & Observations & Mean & Standard Deviation & Minimum & Median & Maximum \\
\hline ROA & 4268 & 0.48 & 0.82 & -9.03 & 0.48 & 9.24 \\
Z-score & 3291 & 3.58 & 1.01 & -1.58 & 3.60 & 9.20 \\
HHIRD & 4268 & 35.89 & 11.32 & 4.74 & 35.50 & 74.17 \\
Loan/TA & 4268 & 65.61 & 16.56 & 0.29 & 69.16 & 97.72 \\
Eq/TA & 4268 & 9.92 & 4.90 & 0.25 & 9.23 & 73.98 \\
NonDep/TL & 4268 & 43.10 & 17.11 & 1.02 & 44.16 & 100.00 \\
CIR & 4268 & 66.08 & 14.66 & 6.50 & 65.45 & 307.14 \\
Size & 4268 & 14.15 & 2.30 & 10.00 & 13.60 & 21.50 \\
NPLr & 4268 & 7.35 & 5.58 & 0.00 & 6.11 & 62.33 \\
HHIIC & 4268 & 485.52 & 361.33 & 151 & 407 & 3700 \\
Inflation & 4268 & 2.13 & 1.01 & -4.48 & 2.07 & 5.65 \\
GDP & 4268 & -0.25 & 2.71 & -8.54 & 0.48 & 6.87 \\
UR & 4268 & 8.38 & 2.72 & 3.10 & 8.40 & 24.80 \\
Interest & 4268 & 1.84 & 1.19 & 0.75 & 1.00 & 4.75 \\
\hline
\end{tabular}

Table 5 reports the dynamic panel data regressions for measures of both bank profitability (ROA) and bank risk (Z-score) using the system-GMM estimator. The high statistical significance in the lagged dependent variables confirms the dynamic character of the model specification.

We show a direct and significant relationship between bank profitability and our proxy of bank diversification. This result is consistent with the part of the literature considering that increasing the share of noninterest activities in banks could be beneficial for returns (e.g., [23,29]). However, we do not find evidence to conclude that the effect of income diversification on bank stability is negative. Therefore, greater diversification could lead banks to obtain greater profits without necessarily implying an increase in their risk.

Regarding control variables in the profitability equation, we find that the effect of capitalization on ROA is positive and highly significant. Athanasoglou et al. [48] stated that this positive impact could be the result of capital acting as a safety net in the cases of adverse developments. This relationship would help banks to finance their assets at more favorable interest rates, increasing expected profitability, and offsetting the cost of equity. Our results also show that non-deposit funding reduces bank profitability (as reported by Laeven and Levine [19] and Saona [36]). The negative sign of the CIR variable and its high statistical significance confirm that improvements in efficiency are translated into improvements in profitability. 
Table 5. The effect of diversification on the profitability and risk of Eurozone banks (2000-2012).

\begin{tabular}{|c|c|c|}
\hline Variables & ROA & Z-Score \\
\hline Dep. Var.t-1 & $\begin{array}{l}0.421^{* *} \\
(0.203)\end{array}$ & $\begin{array}{c}0.477^{* * *} \\
(0.034)\end{array}$ \\
\hline HHIRD & $\begin{array}{c}0.008 * * * \\
(0.002)\end{array}$ & $\begin{array}{l}-0.006 \\
(0.004)\end{array}$ \\
\hline Loan/TA & $\begin{array}{c}0.002 \\
(0.003)\end{array}$ & $\begin{array}{c}-0.006 \text { ** } \\
(0.003)\end{array}$ \\
\hline $\mathrm{Eq} / \mathrm{TA}$ & $\begin{array}{c}0.037^{* * * *} \\
(0.013)\end{array}$ & $\begin{array}{c}0.029^{* * *} \\
(0.008)\end{array}$ \\
\hline NonDep/TL & $\begin{array}{c}-0.006 \text { ** } \\
(0.003)\end{array}$ & $\begin{array}{c}-0.008 \text { ** } \\
(0.004)\end{array}$ \\
\hline CIR & $\begin{array}{c}-0.025^{* * *} \\
(0.002)\end{array}$ & $\begin{array}{l}-0.001 \\
(0.003)\end{array}$ \\
\hline Size & $\begin{array}{c}-0.074 * * \\
(0.030)\end{array}$ & $\begin{array}{c}0.028 \\
(0.057) \\
\end{array}$ \\
\hline NPLr & $\begin{array}{c}-0.076^{* * *} \\
(0.011)\end{array}$ & - \\
\hline ROA & - & $\begin{array}{c}0.284^{* * *} \\
(0.057) \\
\end{array}$ \\
\hline HHIIC & $\begin{array}{c}0.000 * * * \\
(0.000)\end{array}$ & $\begin{array}{l}0.000 * \\
(0.000)\end{array}$ \\
\hline Inflation & $\begin{array}{l}0.039 * \\
(0.021)\end{array}$ & $\begin{array}{c}-0.035 * \\
(0.020)\end{array}$ \\
\hline GDP & $\begin{array}{l}0.011^{*} \\
(0.006)\end{array}$ & $\begin{array}{c}0.061 * * * \\
(0.008)\end{array}$ \\
\hline UR & $\begin{array}{c}-0.039 * * * \\
(0.011) \\
\end{array}$ & $\begin{array}{c}-0.019 * \\
(0.011) \\
\end{array}$ \\
\hline Interest & $\begin{array}{c}0.073^{* * * *} \\
(0.019)\end{array}$ & $\begin{array}{l}0.035^{*} \\
(0.020)\end{array}$ \\
\hline Regulatory Indexes & Yes & Yes \\
\hline Listed dummy & Yes & Yes \\
\hline Bank type dummies & Yes & Yes \\
\hline Constant & $\begin{array}{c}3.725 * * * \\
(0.653) \\
\end{array}$ & $\begin{array}{l}1.664^{*} \\
(0.877) \\
\end{array}$ \\
\hline$z_{1}$ & $1269.62(20)$ & $802.58(20)$ \\
\hline$m_{1}$ & -4.07 & -6.13 \\
\hline$m_{2}$ & -0.81 & -1.05 \\
\hline Hansen & 444.96 (444) & $443.17(444)$ \\
\hline
\end{tabular}

Notes: This table reports the determinants of profitability and risk of Eurozone banks over the period of 2000 to 2012 using the system-generalized method of moments (GMM) estimator. The sample comprises 4268 observations (3291 in the Z-score equation). See Table 3 for a description of the variables. With the exception of industry concentration, macroeconomic variables and bank type dummies, all of the independent variables in our model are considered endogenous. We report heteroskedasticity-consistent asymptotic standard errors in parentheses, and significance levels are indicated as follows: ${ }^{* * *}=$ significant at the $1 \%$ level; ${ }^{* *}=$ significant at the $5 \%$ level; and $*=$ significant at the $10 \%$ level. $z_{1}$ is a Wald test of the joint significance of the reported coefficients, asymptotically distributed as $\chi^{2}$ under the null of no significance, with degrees of freedom in parentheses. $m_{i}$ is a serial correlation test of order $i$ using residuals in first differences, asymptotically distributed as $N(0,1)$ under the null of no serial correlation. Hansen is a test of over-identifying restrictions, asymptotically distributed as $\chi^{2}$ under the null of no correlation between the instruments and the error term, with degrees of freedom in parentheses.

We report that the effect of size on bank profitability is negative. In principle, one would expect that larger banks experience more significant increases in profitability through economies of scale. However, beyond a certain threshold of size, diseconomies of scale can arise, rendering the size of a bank detrimental to its profitability [40]. The effect of NPLr on profitability is negative (see, e.g., [48]). There appears to be a consensus that an increase in doubtful assets, which do not accrue income, requires a bank to allocate a significant portion of its gross margin to provisions to cover expected credit losses; thus, profitability will be lower. Our results suggest a positive relationship between bank concentration and profitability in the Eurozone. As could be expected, bank profitability is directly 
related to GDP growth and is inversely related to unemployment rates. Inflation positively affects bank profitability, indicating that managers might anticipate inflation expectations and adjust interest rates to achieve greater profits [40]. Finally, bank profitability shows a positive correlation with the interest rate on the MRO of the ECB.

We also find significant relationships between the control variables and the Z-score in the risk equation. We report a positive relationship between the relative percentage of loans in the assets of a bank and its risk, based on the literature finding that laxity in lending can be a source of banking problems (e.g., [55]). Our results confirm that the higher the capitalization, the lower the bank risk is. We report that a greater dependence on wholesale funding can increase bank risk. The financial crisis has clearly exposed the risk of wholesale funding, especially after the bankruptcy of Lehman Brothers in 2008 [43]. We also find an inverse relationship between bank profitability and risk (as reported by Baselga-Pascual et al. [43]). With regard to the exogenous variables, we show that the more concentrated that the banking sector is, the lower that the risk tends to be. This result is in line with the empirical evidence that was provided by Beck et al. [56] and Caprio et al. [57]. Among the macroeconomic variables, GDP and UR show negative and positive relationships, respectively, with risk. These findings confirm the abundant support in the literature for the view that bank risk exhibits a clear cyclical behavior [58,59]. We finally reveal a positive relationship between inflation and bank risk, and a negative relationship between interest rates and bank risk.

\subsection{Robustness Checks}

To further confirm the aforementioned findings, we conduct a number of robustness checks (see Table 6).

Table 6. Robustness checks.

\begin{tabular}{|c|c|c|}
\hline \multicolumn{3}{|c|}{ (A) Considering alternative proxies of profitability and risk } \\
\hline & ROE & NPLr \\
\hline HHIRD & $\begin{array}{c}0.132 * * * \\
(0.045)\end{array}$ & $\begin{array}{c}0.003 \\
(0.005)\end{array}$ \\
\hline$z_{1}$ & $1043.94(20)$ & $1059.06(20)$ \\
\hline$m_{1}$ & -4.99 & -6.18 \\
\hline$m_{2}$ & -0.77 & -1.07 \\
\hline Hansen & $447.08(444)$ & $441.60(444)$ \\
\hline \multicolumn{3}{|c|}{ (B) Considering NonINT instead of HHIRD } \\
\hline & ROA & Z-Score \\
\hline NonINT & $\begin{array}{c}0.014^{* * *} \\
(0.003)\end{array}$ & $\begin{array}{l}-0.001 \\
(0.004)\end{array}$ \\
\hline$z_{1}$ & $1332.29(20)$ & $599.33(20)$ \\
\hline$m_{1}$ & -4.05 & -6.13 \\
\hline$m_{2}$ & -0.83 & -1.05 \\
\hline Hansen & $444.85(444)$ & $443.17(444)$ \\
\hline \multicolumn{3}{|c|}{ (C) Including year and country dummies instead of macroeconomic variables } \\
\hline & ROA & Z-score \\
\hline HHIRD & $\begin{array}{c}0.008^{* * *} \\
(0.003)\end{array}$ & $\begin{array}{l}-0.004 \\
(0.006)\end{array}$ \\
\hline$z_{1}$ & $510.98(38)$ & $1424.22(38)$ \\
\hline$m_{1}$ & -4.21 & -5.63 \\
\hline$m_{2}$ & -0.66 & -1.01 \\
\hline Hansen & $435.10(441)$ & $438.82(441)$ \\
\hline
\end{tabular}

Notes: This table presents the results after changing some of the variables included in the baseline regression. The models in section (A) consider alternative proxies of bank profitability and risk. The models in section (B) consider NonINT in place of Herfindahl-Hirschman index (HHIRD). The models in section (C) consider year and country dummies in place of the macroeconomic variables. We also include control variables (not reported) in all of the regressions. With the exception of industry concentration, macroeconomic variables, year, country and bank type dummies, all of the independent variables in our models are considered endogenous. We report heteroskedasticity-consistent asymptotic standard errors in parentheses, and significance levels are indicated as follows: ${ }^{* * *}=$ significant at the $1 \%$ level; ${ }^{* *}=$ significant at the $5 \%$ level; and, ${ }^{*}=$ significant at the $10 \%$ level. $z_{1}$ is a Wald test of the joint significance of the reported coefficients, asymptotically distributed as $\chi^{2}$ under the null of no significance, with degrees of freedom in parentheses. $m_{i}$ is a serial correlation test of order $i$ using residuals in first differences, asymptotically distributed as $N(0,1)$ under the null of no serial correlation. Hansen is a test of over-identifying restrictions, asymptotically distributed as $\chi^{2}$ under the null of no correlation between the instruments and the error term, with degrees of freedom in parentheses. 
First, we re-estimate our baseline equation when considering the return on equity (ROE) as a proxy for profitability and the NPLr as a proxy for risk. Second, we use noninterest income as a percentage of total operating revenue (NonINT), instead of HHIRD as our indicator of revenue diversification. Similarly, we re-estimate the baseline equation to consider year and country dummies in the place of macroeconomic variables. The result does not differ from that obtained previously.

\section{Summary and Conclusions}

This paper empirically analyzes the effect of revenue diversification on bank profitability and bank risk in the Eurozone. We consider a revenue diversification index that reflects the balance of different types of income, such as interest, net commissions, trading, and other operating income. Our sample comprises an unbalanced panel data set of 4268 observations from 2000 to 2012, allowing for us to consider the impact of the recent financial and economic crisis on the Eurozone banking system. Because previous studies have suggested that our regression could be affected by endogeneity, unobserved heterogeneity and the persistence of dependent variables, we employ a dynamic panel data model with the system-GMM estimator.

We provide evidence that higher income diversification favors bank profitability. This result is consistent with the theory that suggests that the potential benefits of diversification arising from economies of scope are larger than its costs (agency problems, regulatory costs, or inefficient internal resource allocation). However, our study does not find a significant relationship between revenue diversification and bank risk, even when considering a crisis period. Therefore, we cannot confirm theoretical predictions about the effect of diversification on either a reduction (according to the portfolio theory) or an increase (due to new forms of risk or lower capital ratios) of bank risk.

Our findings have important policy implications and could have broader significance for supervisors concerned about benchmarking and validation issues that are related to banking regulation. The recent recommendations of policy makers to isolate certain types of activities that would imply restrictions on the universal banking model could reduce the profitability of banks. This outcome, together with an environment of low interest rates, can damage the resilience of the banking system, and thus affect the sustainability of the uneven economic recovery in the Eurozone.

Author Contributions: All of the authors contributed equally to this work.

Acknowledgments: We are grateful to Adrian van Rixer and conference participants in the XXIII Spanish Finance Forum for their valuable comments and suggestions. Special thanks are due to the three anonymous referees and the editor for their guidance and very constructive comments.

Conflicts of Interest: The authors declare no conflicts of interest. 


\section{Appendix A}

Table A1. Description of regulatory and supervisory control variables.

Variable

\section{Description}

The capital stringency index is built by adding two measures of capital stringency: overall and initial capital stringency. Overall capital stringency indicates whether risk elements and value losses are considered while calculating the regulatory capital. It is based on the following questions: (i) Is the minimum capital-asset ratio requirement risk weighted in line with the Basel guidelines? (ii) Does the minimum ratio vary as a function of credit risk? (iii) Does the minimum ratio vary as a function of market risk? (iv) Are market values of loan losses not realized in accounting books deducted from capital? (v) Are unrealized losses in securities portfolios deducted from capital? (vi) Are unrealized foreign exchange losses deducted from capital? (vii) What fraction of revaluation gains is allowed as part of capital? Initial capital stringency refers to whether certain funds may be used to initially capitalize a bank and whether they are officially verified. It is based on the following questions: (viii) Are the sources of funds to be used as capital verified by the regulatory or supervisory authorities? (ix) Can the initial disbursement or subsequent injections of capital be performed with assets other than cash or government securities? (x) Can the initial disbursement of capital be performed with borrowed funds? We assign a (ix) and (x) In addition a value or 1 . we assign a value of 1 if the fraction of revaluation gains that is allowed to count as regulatory capital (question (vii)) is less than 0.75 . Otherwise, we assign a value of 0 .
By adding all these values together, we create the variable capital stringency index, which ranges in value from 0 to 10 , with higher values indicating greater stringency. This index is a measure of the power of supervisory agencies, indicating the extent to which these authorities can take specific actions against bank management and directors, shareholders and bank auditors. This variable is determined by adding 1 if the answer is yes and 0 otherwise for each of the following 14 questions: (i) Doe the supervisory agency have the right to meet with external auditors to discuss their report without the approval of the bank? (ii) Are auditors legally required to communicate directly to the supervisory agency any presumed involvement of bank directors or senior managers in illicit activities, fraud, or insider abuse? (iii) Can supervisors take legal action against external auditors for negligence? (iv) Can the supervisory authorities force a bank to change its internal organizational structure? supervisors take legal action against external auditors for negligence? (iv) Can the supervisory authorities force a bank to change its internal organizational structurs
(v) Does the institution disclose off-balance-sheet items to supervisors? (vi) Can the supervisory agency order the bank's directors or management to constitute

(v) Does the institution disclose off-balance-sheet items to supervisors? (vi) Can the supervisory agency order the bank's directors or management to constitute
provisions to cover actual or potential losses? (vii) Can the supervisory agency suspend directors' decisions to distribute dividends? (viii) Can the supervisory agency suspend directors' decisions to distribute bonuses? (ix) Can the supervisory agency suspend directors' decisions to distribute management fees? (x) Can the supervisory agency supersede bank shareholder rights and declare the bank insolvent? (xi) Does banking law allow a supervisory agency or any other government agency (other than a court) to suspend some or all ownership rights at a problem bank? (xii) Regarding bank restructuring and reorganization, can the supervisory agency or any other government agency (other than a court) supersede shareholder rights? (xiii) Regarding bank restructuring and reorganization, can the supervisory agency or any other government agency (other than a court) remove and replace management? (xiv) Regarding bank restructuring and reorganization, can the supervisory agency or any other government agency (other than a court) remove and replace directors? This index takes values between 0 and 14 , with higher values indicating more supervisory power.

To control for market discipline, we use the private monitoring index. This index examines the degree to which regulatory and supervisory policies encourage the private monitoring of banks, and it is composed of information on (i) whether bank directors and officials are legally liable for the accuracy of information disclosed to the public; (ii) whether banks must publish consolidated accounts; (iii) whether banks must be audited by certified international auditors; (iv) whether 100 percent of the largest 10 banks are rated by international rating agencies; (v) whether off-balance sheet items are disclosed to the public; (vi) whether banks must disclose their risk management procedures to the public; (vii) whether accrued, though unpaid, interest/principal enters the income statement while the loan is still non-performing. (viii) whether subordinated debt is allowable as part of capital and (ix) whether there is no explicit deposit insurance system and no insurance was paid the last time a bank failed. The maximum value of the private monitoring index is 12 , and the minimum value is 0 , where larger values indicate greater regulatory empowerment of the monitoring of banks by private investors.

The score for this variable is determined based on the level of regulatory restrictiveness for bank participation in: (i) securities activities; (ii) insurance activities; (iii) real estate activities and (iv) bank ownership of non-financial firms. These activities can be unrestricted, permitted, restricted, or prohibited and can receive values of 1, 2, 3 , or 4 , respectively. We create an overall index by calculating the summation value of the four categories. This index ranges from 4 to 16 , with higher values indicating higher restrictions. 


\section{References}

1. DeYoung, R.; Roland, K.P. Product mix and earnings volatility at commercial banks: Evidence from a degree of total leverage model. J. Financ. Intermed. 2001, 10, 54-84. [CrossRef]

2. Johnson, R.D.; Meinster, D.R. Bank holding companies: Diversification opportunities in nonbank activities. East. Econ. J. 1974, 1, 316-323.

3. Heggestad, A. Riskiness of investments in nonbank activities by bank holding companies. J. Econ. Bus. 1975, 27, 219-223.

4. Wall, L.D.; Eisenbeis, R.A. Risk considerations in deregulating bank activities. Fed. Reserv. Bank Atl. Econ. Rev. 1984, 69, 6-19.

5. Litan, R.E. Evaluating and controlling the risks of financial product deregulation. Yale J. Regul. 1985, 3, 1-52.

6. Wilmarth, A.E. The Dodd-Frank Act: A Flawed and Inadequate Response to the Too-Big-to-Fail Problem. Or. Law Rev. 2011, 89, 951-1058.

7. Meslier, C.; Tacneng, R.; Tarazi, A. Is bank income diversification beneficial? Evidence from an emerging economy. J. Int. Financ. Mark. Inst. Money 2014, 31, 97-126. [CrossRef]

8. Altunbas, Y.; Manganelli, S.; Marques-Ibanez, D. Bank Risk during the Financial Crisis: Do Business Models Matter? Working Paper 1394; European Central Bank: Frankfurt, Germany, 2011.

9. Liikanen, E. The High-Level Expert Group on Reforming the Structure of the EU Banking Sector: Final Report. 2012. Available online: http:/ / ec.europa.eu/internal_market/bank/docs/high-level_expert_group/report_ en.pdf (accessed on 1 April 2014).

10. Gambacorta, L.; Van Rixtel, A. Structural bank regulation initiatives: Approaches and implications. BANCARIA Bancaria Editrice 2013, 6, 14-27.

11. Baele, L.; De Jonghe, O.; Vander Vennet, R. Does the stock market value bank diversification? J. Bank. Financ. 2007, 31, 1999-2023. [CrossRef]

12. Mercieca, S.; Schaeck, K.; Wolfe, S. Small European banks: Benefits from diversification? J. Bank. Financ. 2007, 31, 1975-1998. [CrossRef]

13. Lepetit, L.; Nys, E.; Rous, P.; Tarazi, A. Bank income structure and risk: An empirical analysis of European banks. J. Bank. Financ. 2008, 32, 1452-1467. [CrossRef]

14. Arellano, M.; Bover, O. Another look at the instrumental-variable estimation of error-components models. J. Econ. 1995, 68, 29-52. [CrossRef]

15. Blundell, R.W.; Bond, S.R. Initial conditions and moment restrictions in dynamic panel data models. J. Econ. 1998, 87, 115-143. [CrossRef]

16. Bun, M.J.G.; Windmeijer, F. The weak instrument problem of the system GMM estimator in dynamic panel data models. Econ. J. 2010, 13, 95-126. [CrossRef]

17. Diamond, D.W. Monitoring and reputation: The choice between bank loans and directly placed debt. J. Polit. Econ. 1991, 99, 689-721. [CrossRef]

18. Stein, J.C. Information production and capital allocation: Decentralized versus hierarchical firms. J. Financ. 2002, 57, 1891-1921. [CrossRef]

19. Laeven, L.; Levine, R. Is there a diversification discount in financial conglomerates? J. Financ. Econ. 2007, 85, 331-367. [CrossRef]

20. Jensen, M.C.; Meckling, W.H. Theory of the firm: Managerial behavior, agency costs and ownership structure. J. Financ. Econ. 1976, 3, 305-360. [CrossRef]

21. Rajan, R.; Servaes, H.; Zingales, L. The cost of diversity: The diversification discount and inefficient investment. J. Financ. 2000, 55, 35-80. [CrossRef]

22. Moudud-Ul-Huq, S.; Nadeem Ashraf, B.; Das Gupta, A.; Zheng, C. Does bank diversification heterogeneously affect performance and risk-taking in ASEAN emerging economies? Res. Int. Bus. Financ. 2018. [CrossRef]

23. Brighi, P.; Venturelli, V. How do income diversification, firm size and capital ratio affect performance? Evidence for bank holding companies. Appl. Financ. Econ. 2014, 24, 1375-1392. [CrossRef]

24. Chiorazzo, V.; Milani, C.; Salvini, F. Income diversification and bank performance: Evidence from Italian banks. J. Financ. Serv. Res. 2008, 33, 181-203. [CrossRef]

25. Köhler, M. Does non-interest income make banks more risky? Retail-versus investment-oriented banks. Rev. Financ. Econ. 2014, 23, 182-193. [CrossRef] 
26. Köhler, M. Which banks are more risky? The impact of business model on bank stability. J. Financ. Stab. 2015, 16, 195-212. [CrossRef]

27. Brighi, P.; Venturelli, V. How functional and geographic diversification affect bank profitability during the crisis. Financ. Res. Lett. 2016, 16, 1-10. [CrossRef]

28. Elsas, R.; Hackethal, A.; Holzhäuser, M. The anatomy of bank diversification. J. Bank. Financ. 2010, 34, 1274-1287. [CrossRef]

29. Lee, C.; Hsieh, M.F.; Yang, S.J. The relationship between revenue diversification and bank performance: Do financial structures and financial reforms matter? Jpn. World Econ. 2014, 29, 18-35. [CrossRef]

30. Sanya, S.; Wolfe, S. Can Banks in Emerging Economies Benefit from Revenue Diversification? J. Financ. Serv. Res. 2011, 40, 79-101. [CrossRef]

31. Nguyen, M.; Perera, S.; Skully, M. Bank market power, ownership, regional presence and revenue diversification: Evidence from Africa. Emerg. Mark. Rev. 2016, 27, 36-62. [CrossRef]

32. Sissy, A.M.; Amidu, M.; Abor, J.Y. The effects of revenue diversification and cross border banking on risk and return of banks in Africa. Res. Int. Bus. Financ. 2017, 40, 1-18. [CrossRef]

33. De Jonghe, O. Back to the basics in banking? A micro-analysis of banking system stability. J. Financ. Intermed. 2010, 19, 387-417. [CrossRef]

34. DeYoung, R.; Rice, T. Noninterest income and financial performance at U.S. commercial banks. Financ. Rev. 2004, 39, 101-127. [CrossRef]

35. Stiroh, K.J.; Rumble, A. The dark side of diversification: The case of US financial holding companies. J. Bank. Financ. 2006, 30, 2131-2161. [CrossRef]

36. Saona, P. Intra and extra bank determinants of Latin American Banks profitability. Int. Rev. Econ. Financ. 2016, 45, 197-214. [CrossRef]

37. Demirgüç-Kunt, A.; Huizinga, H. Bank activity and funding strategies: The impact on risk and returns. J. Financ. Econ. 2010, 98, 626-650. [CrossRef]

38. Arellano, M.; Bond, S.R. Some tests of specification for panel data: Monte Carlo evidence and an application to employment equations. Rev. Econ. Stud. 1991, 58, 277-297. [CrossRef]

39. Delis, M.D.; Staikouras, P.K. Supervisory effectiveness and bank risk. Rev. Financ. 2011, 15, 511-543. [CrossRef]

40. Trujillo-Ponce, A. What determines the profitability of banks? Evidence from Spain. Account. Financ. 2013, 53, 561-586. [CrossRef]

41. Windmeijer, F. A finite sample correction for the variance of linear efficient GMM estimators. J. Econ. 2005, 126, 25-51. [CrossRef]

42. Altunbas, Y.; Carbó, S.; Gardener, E.P.M.; Molyneux, P. Examining the relationships between capital, risk and efficiency in European banking. Eur. Financ. Manag. 2007, 13, 49-70. [CrossRef]

43. Baselga-Pascual, L.; Trujillo-Ponce, A.; Cardone-Riportella, C. Factors influencing bank risk in Europe: Evidence from the financial crisis. N. Am. J. Econ. Financ. 2015, 34, 138-166. [CrossRef]

44. Laeven, L.; Majnoni, G. Loan loss provisioning and economic slowdowns: Too much, too late? J. Financ. Intermed. 2003, 12, 178-197. [CrossRef]

45. Bikker, J.A.; Metzemakers, P. Bank provisioning behavior and procyclicality. J. Financ. Mark. Inst. Money 2005, 15, 141-157. [CrossRef]

46. Agoraki, M.-E.K.; Delis, M.D.; Pasiouras, F. Regulations, competition and bank risk-taking in transition countries. J. Financ. Stab. 2011, 7, 38-48. [CrossRef]

47. Louzis, D.; Vouldis, A.T.; Metaxas, V. Macroeconomic and bank-specific determinants of non-performing loans in Greece: A comparative study of mortgage, business and consumer loan portfolios. J. Bank. Financ. 2012, 36, 1012-1027. [CrossRef]

48. Athanasoglou, P.P.; Brissimis, S.N.; Delis, M.D. Bank-specific, industry-specific and macroeconomic determinants of bank profitability. J. Int. Financ. Mark. Inst. Money 2008, 18, 121-136. [CrossRef]

49. Claeys, S.; Vander Vennet, R. Determinants of bank interest margins in Central and Eastern Europe: A comparison with the West. Econ. Syst. 2008, 32, 197-216. [CrossRef]

50. García-Herrero, A.; Gavilá, S.; Santabárbara, D. What explains the low profitability of Chinese banks? J. Bank. Financ. 2009, 33, 2080-2092. [CrossRef]

51. Barth, J.R.; Caprio, G., Jr.; Levine, R. The Regulation and Supervision of Bank around the World: A New Database; Policy Research Working Paper 2588; World Bank: Washington, DC, USA, 2001. 
52. Barth, J.R.; Caprio, G., Jr.; Levine, R. Bank regulation and supervision in 180 countries from 1999 to 2011. J. Financ. Econ. Policy 2013, 5, 111-219. [CrossRef]

53. Nichols, D.; Wahlen, J.; Wieland, M. Publicly-traded versus privately-held: Implications for conditional conservatism in bank accounting. Rev. Account. Stud. 2009, 14, 88-122. [CrossRef]

54. Barth, J.R.; Caprio, G., Jr.; Levine, R. Bank regulation and supervision: What works best? J. Financ. Intermed. 2004, 13, 205-248. [CrossRef]

55. Festić, M.; Kavkler, A.; Repina, S. The macroeconomic sources of systemic risk in the banking sectors of five new EU member states. J. Bank. Financ. 2011, 35, 310-322. [CrossRef]

56. Beck, T.; Demirgüc-Kunt, A.; Levine, R. Bank concentration, competition, and crises: First results. J. Bank. Financ. 2006, 30, 1581-1603. [CrossRef]

57. Caprio, G., Jr.; D'Apice, V.; Ferri, G.; Puopolo, G.W. Macro-financial determinants of the great financial crisis: Implications for financial regulation. J. Bank. Financ. 2014, 44, 114-129. [CrossRef]

58. Marcucci, J.; Quagliariello, M. Is bank portfolio riskiness procyclical? Evidence from Italy using a vector autoregression. J. Int. Financ. Mark. Inst. Money 2008, 18, 46-63. [CrossRef]

59. Uhde, A.; Heimeshoff, U. Consolidation in banking and financial stability in Europe: Empirical evidence. J. Bank. Financ. 2009, 33, 1299-1311. [CrossRef]

(C) 2018 by the authors. Licensee MDPI, Basel, Switzerland. This article is an open access article distributed under the terms and conditions of the Creative Commons Attribution (CC BY) license (http:/ / creativecommons.org/licenses/by/4.0/). 